\title{
Eksperimen Mandiri Siswa dalam Penentuan Percepatan Gravitasi Bumi pada Materi Gerak Jatuh Bebas
}

\author{
Thoha Firdaus $^{1 *}$, Erwin ${ }^{2}$, dan Rosmiati ${ }^{3}$ \\ 1,2 Pendidikan Fisika, STKIP Nurul Huda \\ 3 Pendidikan Fisika, STKIP Bima \\ 1,2,3 Pascasarjana Pendidikan IPA, Universitas Pendidikan Indonesia \\ *E-mail: thohaf@stkipnurulhuda.ac.id
}

\begin{abstract}
Abstrak
Siswa selalu berpikir bahwa jumlah massa mempengaruhi percepatan jatuh benda vertikal. Melalui eksperimen mandiri yang dilakukan siswa kelas $\mathrm{X}$, akan mengubah cara berpikir siswa dengan benar. Tujuan penelitian ini adalah menentukan berapa waktu tempuh yang dimiliki dua benda yang mengalami gerak jatuh bebas dengan massa yang berbeda. Eksperimen menggunakan media gerak jatuh bebas yang terintegrasi oleh komputer/laptop. Eksperimen didampingi oleh guru, kemudian mereka menyimpulkan sendiri hasil dari analisis yang didapatkan. Hasil yang didapat siswa untuk kedua benda masing-masing adalah 0,4904 s dan 0,4828 s.
\end{abstract}

Kata kunci: Eksperimen mandiri siswa, percepatan jatuh benda, gerak jatuh bebas.

\section{PENDAHULUAN}

Guru merupakan subjek terpenting, meskipun tugas guru hanya sampai sebagai fasilitator dalam terselenggaranya pembelajaran di kelas. Tugas utama seorang guru adalah mengembangkan kemampuan konsep siswa. Namun demikian fasilitator perlu mampu mengaitkan dengan pengalaman menggunakan pendekatan, strategi, kaidah dan teknik pembelajaran yang lebih bersifat kontekstual (Abdullah, 2005). Bagaimanapun bagus dan idealnya kurikulum pendidikan, lengkapnya sarana dan prasarana pendidikan, tanpa diimbangi dengan kemampuan guru dalam mengimplementasikannya, maka semuanya akan kurang bermakna (Esi, Purwaningsih, \& Okianna, 2016). Kemampuan guru menggunakan media yang tepat dalam pembelajaran materi khusus, merupakan satu indikator kemampuan Pedagogical Content Knowledge (PCK). Sebuah penelitian pada suatu perguruan tinggi di Provinsi Sumatera Selatan, menunjukkan masih rendahnya pemahaman calon guru fisika pada beberapa komponen PCK (Erwin \& Rustaman, 2017).

Tugas guru sebagai fasilitator, mendorong siswa untuk melakukan pembelajaran mandiri. Melalui pembelajaran mandiri, siswa akan lebih giat mandiri dalam mengetahui permasalahan dan bagaimana menyelesaikan permasalahan yang dihadapinya. Menurut Nuraeni et al. (2012) kemandirian belajar seseorang sangat tergantung pada seberapa jauh seseorang tersebut dapat belajar mandiri. Dalam belajar mandiri, siswa akan berusaha untuk mempelajari serta memahami isi pelajaran yang di baca atau dilihatnya.

Fisika umumnya diakui sebagai konseptual sulit karena pembelajaran fisika terdiri dari konsepkonsep yang berkaitan dengan kehidupan nyata (Firdaus, Setiawan, \& Hamidah, 2017). Selain itu, siswa juga berpikir bahwa belajar fisika sulit dipahami. Telah ditegaskan oleh Ekici (2016) bahwa siswa menganggap konsep dalam fisika terlalu abstrak untuk dipahami. Oleh karenanya perlu adanya media yang tepat untuk mampu menjelaskan pemahaman yang sulit menjadi lebih mudah.

Gerak Jatuh Bebas (GJB), merupakan materi yang wajib didapatkan pada siswa kelas X sekolah menengah. Pemahaman gerak jatuh bebas pada siswa sering di temui masalah karena miskonsepsi mereka, diantaranya yaitu mengenai percepatan jatuh benda. Siswa sering berpikir bahwa jika massa mempengaruhi percepatan benda jatuh vertikal ke bawah. Sebelum masa Galileo juga pernah terjadi, orang mempercayai pemikiran bahwa benda yang lebih berat jatuh lebih cepat dari benda yang lebih ringan, dan bahwa laju jatuh benda tersebut sebanding dengan berat benda itu (Sumarsono, 2008). 
Dalam kasus lain yang baru-baru ini dilakukan Venkadasalam \& Ganea (2018) melalui penelitian pretestnya, beberapa anak diminta untuk membuat prediksi tentang pasangan benda-benda yang memiliki berat yang sama atau berbeda. Skor pretest menunjukkan bahwa banyak anak mulai dengan kesalahpahaman bahwa benda yang lebih berat jatuh lebih cepat daripada objek yang lebih ringan. Salah satu cara untuk memberikan pemahaman yang benar mengenai percepatan gerak jatuh benda adalah melalui percobaan.

\section{Desain Media}

\section{METODE/EKSPERIMEN}

Pengembangan media yang dijadikan eksperimen mandiri telah dibuat oleh guru yang sebelumnya telah diuji. Pengembangan alat diadaptasi dari penelitian Nurdila, Astuti, Rochmaniyah, \& Ishafit (2012) seperti pada kerangka dasar pada gambar 1.

Sistem kerja media adalah diawali dengan sebuah magnet dijatuhkan pada ujung paralon yang telah diberi lilitan. Lilitan ini mempunyai penyambung ke lilitan dasar dengan panjang/tinggi $128 \mathrm{~cm}$, yang kemudian disambungkan pada jack laptop. Ketika magnet melewati kedua lilitan/kumparan (atas dan dasar), laptop yang telah dipasang aplikasi Audacity merekam waktu tempuh yang dialami benda. Waktu yang didapat ini dijadikan data untuk kemudian dianalisis.

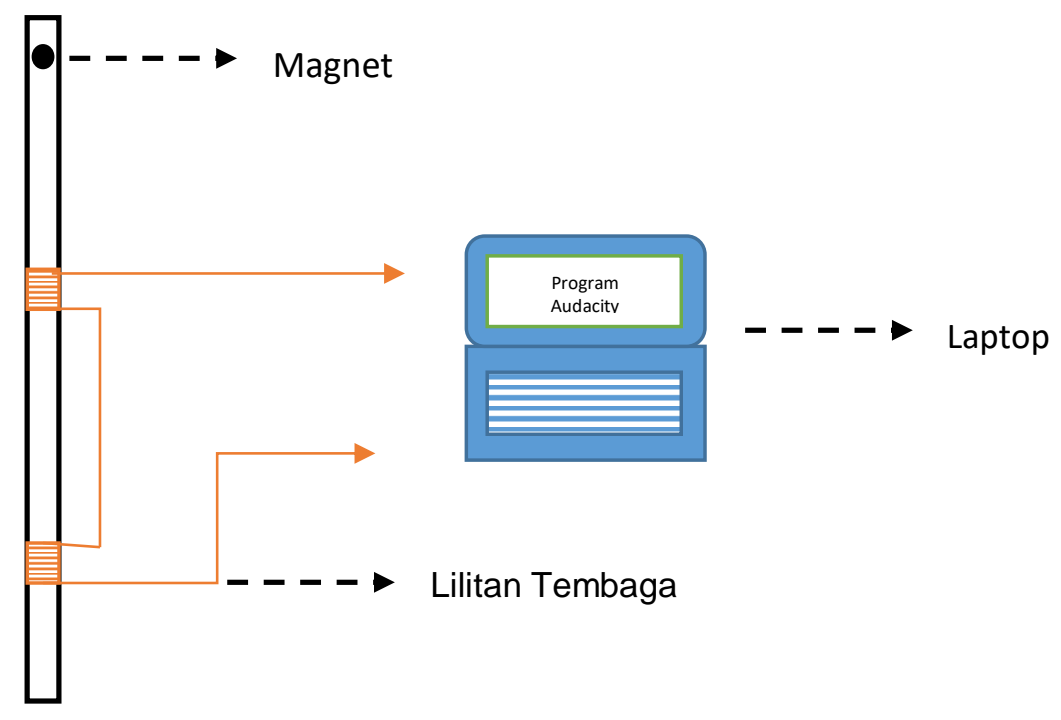

Gambar 1. Kerangka dasar pembuatan media

\section{Metode Eksperimen}

Penelitian ini dilakukan pada sebuah Sekolah Menengah di kota Bandung, sebagai tempat interpretasi hasil penelitian. Siswa sebagai subjek penelitian kelas $X$ semester ganjil tahun akademik 2017/2018. Penelitian ini menggunakan metode pembelajaran demonstrasi siswa. Eksperimen dilakukan oleh kelompok siswa (seperti gambar 1) yang terbagi atas 3 tugas; menyiapkan magnet untuk kemudian dijatuhkan, melihat waktu tempuh ketika magnet dijatuhkan, dan yang satunya menuliskan hasil dari data eksperimen. Sementara kelompok siswa yang lain memperhatikan dan membatu menganalisis data temuan yang didapatkan. Kegiatan eksperimen ini kemudian dapat bergantian dengan kolompok yang berbeda, namun hasil temuan yang di eksplor dalam penelitian ini hanya sampai kepada satu kelompok. 


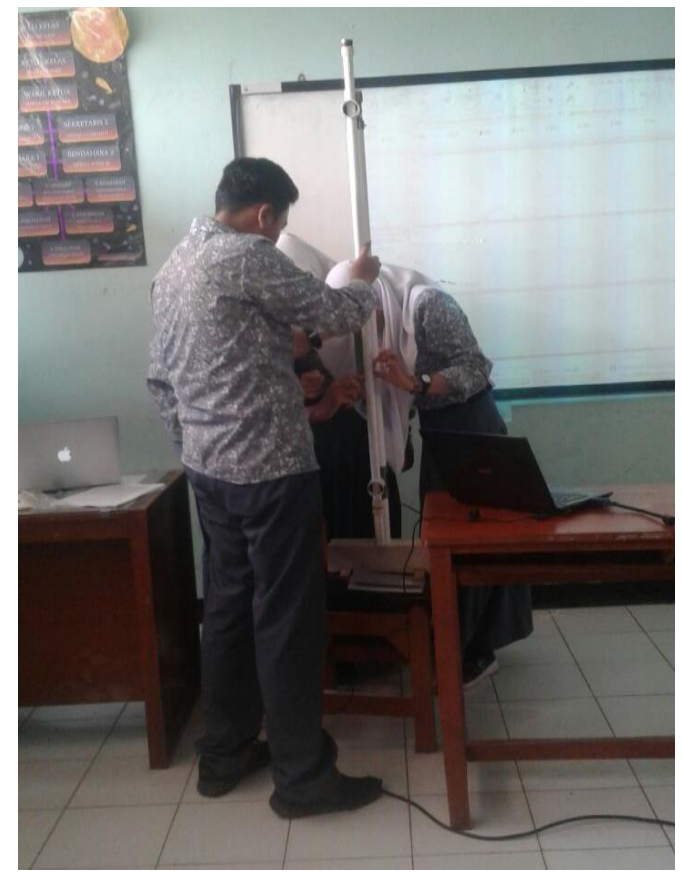

Gambar 2. Kegiatan eksperimen mandiri siswa

Sedangkan langkah pembelajaran diawali dengan guru menjelaskan pentingnya teknologi kepada siswa, kemudian guru memberikan penjelasan sistem kerja dari media gerak jatuh bebas. Setelah selesai menjelaskan sistem kerja, guru meminta satu kelompok untuk maju ke depan untuk mendemonstrasikan sekaligus praktikum media gerak jatuh bebas. Namun dalam hal ini guru mendampingi jika ada kesalahan dari siswa. Tahap terakhir adalah hasil praktikum dari siswa di depan kelas dianalisis bersama-sama dengan siswa lain.

\section{Analisis Data}

Percobaan dilakukan menggunakan 2 (dua) magnet yang berbeda massanya. Magnet berbentuk silinder-silinder kecil. Magnet pertama yang digunakan 2 (dua) silinder, sedangkan magnet kedua berjumlah 8 (delapan) silinder. Untuk tiap-tiap magnet dilakukan percobaan sejumlah 5 (lima) kali percobaan, untuk kemudian hasil akhir sebagaimana persamaan 1:

$$
\overline{\triangle t}=\frac{\sum t_{2}-t_{1}}{n}=\frac{\Delta t}{n}
$$

dengan $\overline{\Delta t}$ adalah jumlah rata waktu, $t_{2}$ adalah waktu sampai di dasar, $t_{1}$ adalah waktu pertama magnet dijatuhkan, $\Delta t$ adalah waktu antara kedua lilitan dan $n$ adalah jumlah percobaan. Hasil analisis ini kemudian dapat digunakan untuk menentukan percepatan gravitasi sebagaimana persamaan 2 :

$$
g=\frac{2 h}{t^{2}}
$$

\section{HASIL DAN PEMBAHASAN}

\section{Hasil}

Dari praktikum siswa, untuk magnet pertama (2 buah magnet) didapatkan hasil sebagaimana pada tabel 1. Dari hasil tabel 1 didapatkan rata-rata waktu yang didapatkan adalah 0,4904 s. 
Tabel 1. Hasil praktikum siswa pada magnet 1.

\begin{tabular}{cc}
\hline \multicolumn{2}{c}{ Magnet 1 } \\
\hline Percobaan 1 & $\Delta t$ \\
\hline 1 & 0,485 \\
2 & 0,493 \\
3 & 0,493 \\
4 & 0,487 \\
5 & 0,494 \\
\hline$\overline{\Delta t}$ & 0,4904
\end{tabular}

Sedangkan praktikum siswa untuk magnet ke 2 (8 buah silinder) didapatkan hasil sebagaimana pada tabel 2. Dari hasil tabel 2 didapatkan rata-rata waktu yang didapatkan adalah 0,4828 s.

Tabel 2. Hasil praktikum siswa pada massa 2

\begin{tabular}{cc}
\hline \multicolumn{2}{c}{ Magnet 2 } \\
\hline Percobaan 1 & $\Delta t$ \\
\hline 1 & 0,483 \\
2 & 0,476 \\
3 & 0,486 \\
4 & 0,486 \\
5 & 0,483 \\
\hline$\overline{\Delta t}$ & 0,4828 \\
\hline
\end{tabular}

\section{Pembahasan}

Dengan melakukan demonstrasi praktikum mandiri, siswa lebih terlibat karena mereka sendiri yang melaksanakan kegiatan percobaan yang dibimbing oleh guru, kemudian dapat melatih siswa untuk berpikir kritis terhadap masalah yang dihadapi saat kegiatan eksperimen berlangsung. Selain itu dengan melakukan praktikum mandiri siswa memperoleh keterampilan mendalam menggunakan peralatan eksperimen (Rohman \& Lusiyana, 2017). Terlihat juga dari kegiatan yang berlangsung, siswa terlihat kompak dengan yang lainnya. Siswa yang satu dengan yang lainnya saling membantun dan mengingatkan.

Temuan sebelumnya dilakukan oleh Sugiyarto (2009), bahwa model pembelajaran acative learning yang diterapkan melalui pendekatan problem-based learning salah satunya dengan introduksi penerapan praktikum mandiri terbukti memberikan sumbangan berarti dalam mengatasi masalah kejenuhan dalam rutinitas proses belajar-mengajar, serta rendahnya aktivitas-kreativitas mahasiswa. Dengan melakukan praktikum mandiri, siswa menjadi lebih aktif dan tidak ada ruang yang membatasi mereka untuk kreatif dan bereksprolasi.

Kemudian temuan eksperimen dilakukan oleh Nurdila et al. (2012), bahwa untuk mendapatkan nilai t dengan menjatuhkan magnet ke dalam pralon yang sudah ada 3 lilitan dengan jarak yang sama $(h 1=h 2)$ dan direkam oleh audacity 1.3 beta (Unicode) dan sinyal ditampilkan dalam bentuk tiga buah gelombang dengan jarak yang berbeda. Dari gelombang ini diperoleh nilai waktu untuk masing-masing jarak lilitan. Setelah semua data diperoleh, data dianalisis dengan regresi linier. Nilai percepatan gravitasi yang diperoleh dari eksperimen dibandingkan dengan nilai acuan yaitu sebesar $9,78 \mathrm{~m} / \mathrm{s} 2$.

Magnet 1 dengan magnet 2 mempunyai massa yang cukup jauh berbeda, namun rata-rata waktu yang didapatkan tidak jauh berbeda. Ini dikarenakan massa tidak mempengaruhi kecepatan benda yang jatuh, dengan asumsi hanya ada gravitasi yang bekerja di atasnya (Duran \& Bryan, 2005).

Kemudian demonstrasi yang lebih dramatis pernah dilakukan di permukaan bulan (di ruang hampa udara) yaitu Astronot David Scott dengan menjatuhkan palu batu dan bulu elang pada saat yang sama selama misi 15 bulan Apollo pada tahun 1971. Sesuai dengan teori, kedua benda itu mendarat di permukaan bulan secara bersamaan (Elert, 2018).

Hasil dari kecepatan gravitasi bumi mempunyai selisih yang kurang signifikan dengan hasil teori yaitu $10,64 \mathrm{~m} / \mathrm{s}^{2}$ dan $10,98 \mathrm{~m} / \mathrm{s}^{2}$ berdasarkan persamaan 2 . Kesalahan ini bisa dikarenakan kedudukan posisi jarak antara pusat bumi. Atau bisa dikarenakan tingkat ketelitian dalam pengambilan skala pada 
program Audacity, dikarenakan program ini pada dasarnya bukan untuk program fisika, namun program perekam audio yang dimanfaatkan. Kesalahan ini bisa juga disebabkan karena hambatan udara, satusatunya cara untuk melakukan percobaan ini tanpa adanya hambatan udara adalah di ruangan vakum hampa udara, namun itu hampir tidak mungkin dilakukan di kelas.

\section{PENUTUP}

Hasil eksperimen yang didapat siswa terlihat bahwa tidak ada perbedaan yang signifikan waktu tempuh antara kedua benda yang memiliki masa yang berbeda. Melalui kegiatan eksperimen mandiri siswa, mengubah pola pikir mereka bahwa percepatan gravitasi bumi tidak dipengaruhi oleh massa benda. Melalui kegiatan eksperimen mandiri siswa, kegiatan eksplorasi siswa akan menjadi lebih natural dan terstruktur, karena mereka aktif dalam hal positif dalam pembelajaran.

\section{UCAPAN TERIMAKASIH}

Kami ucapkan terima kasih kepada guru kami bapak Dadi Rusdiana yang telah memberi ilmu, sport dan kemampuan kepada kami untuk melakukan kegiatan penelitian ini. Kami juga ucapkan terima kasih kepada Sekolah Pascasarjana Program Studi Pendidikan IPA Universitas Pendidikan Indonesia yang telah mendanai untuk proses dan pembuatan alat praktikum gerak jatuh bebas ini. Selain itu tidak tertinggal, kami ucapkan terima kasih kepada sekolah yang telah membantu kami memfasilitasi kegiatan penelitian ini.

\section{DAFTAR PUSTAKA}

Abdullah, S. (2005). Guru sebagai fasilitator. PTS Professional. PTS Professional. Retrieved from https://books.google.com/books?hl=en\&lr=\&id=Ca4noKpe95AC\&oi=fnd\&pg=PT12\&dq=Guru+pu la+bertindak+sebagai+fasilitator+dimana+pembelajaran+berpusatkan+murid+dilaksanakan+unt uk+memberi+peluang+kepada+murid+mengemukakan+idea+mereka+melalui+aktiviti+yang+dija Ian

Duran, B., \& Bryan, K. (2005). Does mass affect the speed of a falling object? Retrieved November 19, 2018, from http://www.csun.edu/scied/4-discrpeant-event/how_fast_do_things_fall/index.htm

Ekici, E. (2016). "Why Do I Slog Through the Physics?": Understanding high school students' difficulties in learning physics. Journal of Education and Practice, 7(7), 95-107.

Elert, G. (2018). Free Fall - The Physics Hypertextbook. Retrieved November 19, 2018, from https://physics.info/falling/

Erwin, E., \& Rustaman, N. Y. (2017). Understanding of Prospective Physics Teachers Students Toward Pedagogical Content Knowledge on Optical Geometry Materials. Journal of Physics: Conference Series, 895(1), 0-7. https://doi.org/10.1088/1742-6596/895/1/012102

Esi, Purwaningsih, E., \& Okianna. (2016). PERANAN GURU SEBAGAI FASILITATOR DAN MOTIVATOR DALAM MENINGKATKAN HASIL BELAJAR DI KELAS XI SMK. Jurnal Pendidikan Dan Pembelajaran, 5(10). Retrieved from http://jurnal.untan.ac.id/index.php/jpdpb/article/view/17132/14624

Firdaus, T., Setiawan, W., \& Hamidah, I. (2017). The Kinematic Learning Model using Video and Interfaces Analysis. Journal of Physics: Conference Series, 895, 012108. https://doi.org/10.1088/1742-6596/895/1/012108

Nuraeni, Fatmaryanti, S. D., \& Ashari. (2012). Peningkatan Kemandirian Belajar IPA melalui Pembelajaran Kooperatif Tipe Group Investigation ( GI ) di Kelas VIII SMP Negeri 33 Purworejo Tahun Pelajaran 2011 / 2012. RADIASI: Jurnal Berkala Pendidikan Fisika, 1(1), 15-18. Retrieved from http://ejournal.umpwr.ac.id/index.php/radiasi/article/view/233

Nurdila, F. A., Astuti, I. A. D., Rochmaniyah, T., \& Ishafit. (2012). Penentuan Percepatan Gravitasi Bumi dengan Eksperimen Terkomputerisasi pada Benda Jatuh Bebas. In Seminar Nasional Quantum 
36 | Titian IImu: Jurnal IImiah Multi Sciences Vol. 11 No. 1, Januari 2019

2012 (pp. 71-75). Yogyakarta: Pendidikan Fisika UAD. Retrieved from https://irnien.files.wordpress.com/2016/09/penentuan-percepatan-gravitasi-bumi-irninagustina.pdf

Rohman, F., \& Lusiyana, A. (2017). Pengembangan Modul Praktikum Mandiri Sebagai Asesmen Keterampilan Proses Sains dan Keterampilan Sosial Mahasiswa. JIPFRI: Jurnal Inovasi Pendidikan Fisika Dan Riset IImiah, 1(2), 47-56. https://doi.org/10.30599/jipfri.v1i2.115

Sugiyarto, S. (2009). Peningkatan Kualitas Pembelajaran Dalam Bidang Ekologi di Perguruan Tinggi Melalui Penerapan Praktikum Mandiri. Prosiding Seminar Biologi, 6(1). Retrieved from http://jurnal.fkip.uns.ac.id/index.php/prosbio/article/view/1377

Sumarsono, J. (2008). Fisika: Untuk SMA/MA Kelas X. (D. Nuraini, Ed.). Jakarta: CV Teguh Karya.

Venkadasalam, V. P., \& Ganea, P. A. (2018). Do objects of different weight fall at the same time? Updating naive beliefs about free-falling objects from fictional and informational books in young children. Journal of Cognition and Development, 19(2), 165-181. https://doi.org/10.1080/15248372.2018.1436058 